\title{
Interaction between milk allowance and fat content of the starter feed on performance of Holstein calves
}

\author{
G. Araujo, ${ }^{*}$ M. Terré, ${ }^{*}$ and A. Bach ${ }^{*}{ }^{1}$ \\ *Department of Ruminant Production, Institut de Recerca i Tecnologia Agroalimentaries (IRTA), Torre Marimon, 08140 Caldes de Montbui, Spain \\ †Institució Catalana de Recerca i Estudis Avançats (ICREA), 08010 Barcelona, Spain
}

\begin{abstract}
Sixty-six Holstein male calves $[42 \pm 6.0 \mathrm{~kg}$ of body weight (BW) and $12 \pm 3.1 \mathrm{~d}$ of age] were housed individually and allocated to 1 of 4 treatments following a $2 \times 2$ factorial complete randomized design to assess the potential interaction between milk replacer (MR) allowance and fat content in the starter feed. Thus, 4 treatments were evaluated: a low-fat ( $4.1 \%$ fat; LF) starter feed offered along with $4 \mathrm{~L} / \mathrm{d}$ of MR (4LF), a high-fat ( $11.2 \%$ fat; HF) starter feed plus $4 \mathrm{~L} / \mathrm{d}$ of MR (4HF), a LF starter feed offered with $6 \mathrm{~L} / \mathrm{d}$ of $\mathrm{MR}$ (6LF), and an HF starter feed offered with $6 \mathrm{~L} / \mathrm{d}$ of MR (6HF). Calves were fed either 4 or $6 \mathrm{~L} / \mathrm{d}$ of MR ( $25 \%$ crude protein and $19.2 \%$ fat) in 2 offers (0800 and $1630 \mathrm{~h}$ ) and had ad libitum access to either an LF or an HF starter feed (21.4 and $22.3 \%$ crude protein). Calves were weaned at wk 6 of study by halving the daily MR allowance for $1 \mathrm{wk}$. Individual MR and starter feed intakes were recorded daily and $\mathrm{BW}$ was determined weekly. A glucose tolerance test was performed on d 30 of study to evaluate the effects of increased energy provision on glucose metabolism. Apparent feed digestibility was measured for the last $5 \mathrm{~d}$ of study. Overall, fat content of starter feed had no effect on solid feed intake. However, during wk 8 of study (after weaning), calves in the LF treatment had greater starter feed intake than $\mathrm{HF}$ calves. Calves on $6 \mathrm{~L} / \mathrm{d}$ of $\mathrm{MR}$ had greater BW than calves fed $4 \mathrm{~L} / \mathrm{d}$ from the second week of study until weaning. After weaning, $6 \mathrm{LF}$ calves had lesser BW than $6 \mathrm{HF}$ calves. Calves on $6 \mathrm{~L} / \mathrm{d}$ of MR had greater average daily gain than calves fed $4 \mathrm{~L} / \mathrm{d}$, and $6 \mathrm{HF}$ calves tended to have the greatest average daily gain. Glucose clearance rate tended to be lesser for $\mathrm{HF}$ than for LF calves. In conclusion, offering $6 \mathrm{~L} / \mathrm{d}$ of MR increased growth performance before weaning and, when offering $6 \mathrm{~L} / \mathrm{d}$ of MR, feeding a high-fat starter feed resulted in the greatest BW after weaning.
\end{abstract}

Key words: calf, energy, fat, growth, starter grain

Received April 24, 2014.

Accepted July 9, 2014.

${ }^{1}$ Corresponding author: alex.bach@irta.cat

\section{INTRODUCTION}

In the last years, the dairy industry has progressively changed from a restricted allowance of about $4 \mathrm{~L} / \mathrm{d}(0.5$ $\mathrm{kg} / \mathrm{d}$ of DM) of milk or milk replacer (MR) to more generous allowances $(6 \mathrm{~L} / \mathrm{d}$ or more), partly because it has been shown that fostering rapid growth early in life might have positive consequences on future milk performance (Davis Rincker et al., 2011; Bach, 2012) and survivability to second lactation (Bach, 2011). However, increasing milk or MR allowances to more than $0.8 \mathrm{~kg} / \mathrm{d}$ reduces starter feed intake (Cowles et al., 2006; Hill et al., 2010; Davis Rincker et al., 2011), rumen development (Terré et al., 2007; Suárez-Mena et al., 2011), and postweaning ADG (Jasper and Weary, 2002; Cowles et al., 2006; Hill et al., 2007) mainly due to insufficient starter feed intake and depressed feed efficiency and digestibility after weaning. Thus, when offering increased amounts of milk or MR, it is especially important to stimulate solid feed consumption to avoid declines in performance and impairments of health after weaning.

A plausible method to stimulate solid feed intake consists of offering palatable ingredients. In a cafeteria study evaluating energy and protein feeds, Montoro and Bach (2012) showed that the most preferred ingredient for young calves was soybean meal (rich in protein), followed by corn and whole soybean (rich in fat and protein). The increased consumption of soybean products by young calves could have been due to oro-sensory preferences but may also have resulted from an attempt by the calves to meet specific nutrient requirements. In the study by Montoro and Bach (2012), it was surprising that calves consumed the different ingredients offered free-choice in such a way that the final nutrient composition of the diet was $29 \% \mathrm{CP}, 6.3 \%$ fat, and about 3.73 Mcal of ME/kg (DM basis). These figures differ from the commonly used nutrient composition of commercial starter feeds in Europe, which contain $20 \% \mathrm{CP}, 4 \%$ fat, and $3.20 \mathrm{Mcal}$ of ME/kg (DM basis). Thus, it could be hypothesized that solid feed intake of calves may be fostered by feeding starter feeds with greater amounts of energy or fat than those currently 
provided. However, increasing the fat content of starter feeds up to $7.3 \%$ DM using whole soybeans (Kuehn et al., 1994) or to greater amounts (up to 20\%) using brown grease and hydrogenated cottonseed oil (Miller et al., 1959) has been reported to reduce DM intake and weight gain. In contrast, Johnson et al. (1956) reported that feeding a high-fat starter (up to 10\% fat) to calves limit-fed whole milk did not affect solid feed intake and increased feed efficiency. Nevertheless, all former studies evaluating the effects of fat addition to starter feeds were conducted in conjunction with low milk allowances $(\leq 0.5 \mathrm{~kg}$ of $\mathrm{DM} / \mathrm{d})$. Moreover, providing large volumes of MR in 2 daily meals (Bach et al., 2013a) or feeding diets rich in fat (Kubota et al., 1999) may lead to insulin resistance.

Thus, the aim of the present study was to evaluate the consequences on growth performance and insulin sensitivity of calves fed starter feeds with 2 different amounts of fat (and energy density) when offering either a restricted or a high milk allowance.

\section{MATERIALS AND METHODS}

\section{Animals and Treatments}

Sixty-six Holstein male calves $(42 \pm 6.0 \mathrm{~kg}$ of BW and $12 \pm 3.1 \mathrm{~d}$ of age) were purchased from commercial farms, and brought to and raised in the facilities of Institut de Recerca i Tecnologia Agroalimentaries (IRTA) at Torre Marimon (Caldes de Montbui, Spain). Before arrival at our facilities, calves received 2 daily allowances of $2 \mathrm{~L}$ of MR (at $12.5 \%$ dilution) and had free access to a starter feed. The composition of MR and starter feeds offered to calves before the beginning of the study differed among farm sources. Calves were kept in individual hutches $(1.6 \times 1.0 \mathrm{~m})$ bedded with sawdust, and were managed according to the guidelines of the Animal Care Committee of IRTA. A milk replacer (Sprayfo Excellent 60, Sloten BV, Deventer, the Netherlands) containing 25\% CP and $19.2 \%$ fat (on a DM basis) was offered twice daily (at 0800 and $1630 \mathrm{~h}$ ) at $10 \% \mathrm{DM}$ concentration for the first $2 \mathrm{~d}$, and then increased to $12.5 \%$ DM thereafter. Animals were randomly assigned to a $2 \times 2$ factorial experiment in which half of the calves were fed $4 \mathrm{~L}$ of MR per day and the other half received $6 \mathrm{~L}$ of MR per day, both at $12.5 \%$ DM concentration. From d 0 of study, calves had ad libitum access to a pelleted starter feed (Table 1) containing either 4.1 or $11.2 \%$ fat (DM basis). Thus, 4 treatments were evaluated: a low-fat $(4.1 \%$; LF) starter feed offered with $4 \mathrm{~L} / \mathrm{d}$ of MR (4LF), a high-fat $(11.2 \%$ fat; HF) starter feed in conjunction with $4 \mathrm{~L} / \mathrm{d}$ of MR $(\mathbf{4 H F})$, an LF starter feed offered with $6 \mathrm{~L} / \mathrm{d}$ of $\mathrm{MR}$ $(6 \mathbf{L F})$, and an HF starter feed offered with $6 \mathrm{~L} / \mathrm{d}$ of
Table 1. Ingredient and nutrient composition (DM basis) of the starter feeds

\begin{tabular}{lcc}
\hline Item & Low fat & High fat \\
\hline Ingredient, \% & & \\
Barley & 25 & 5 \\
Wheat & 15 & 5 \\
Corn & 26 & 42.8 \\
Soybean meal & 24.8 & - \\
Soybean full fat & - & 37.1 \\
Wheat middlings & 9.1 & 10.0 \\
Sodium chloride & 0.03 & 0.03 \\
Premix & 0.04 & 0.04 \\
Nutrient composition & & \\
CP, \% & 21.4 & 22.3 \\
NDF, \% & 16.0 & 14.9 \\
ADF, \% & 7.6 & 6.2 \\
Ether extract, \% & 4.1 & 11.2 \\
Ash, \% & 4.4 & 4.6 \\
ME, Mcal/kg & 3.35 & 3.74 \\
NFC, $\%$ & 54.1 & 47.0 \\
\hline
\end{tabular}

${ }^{1}$ Premix composition: $10,000,000 \mathrm{IU} / \mathrm{kg}$ of vitamin $\mathrm{A} ; 2,000,000 \mathrm{IU} / \mathrm{kg}$ of vitamin $\mathrm{D}_{3} ; 6,000 \mathrm{IU} / \mathrm{kg}$ of vitamin $\mathrm{E} ; 0.5 \mathrm{~g} / \mathrm{kg}$ of vitamin $\mathrm{B}_{1} ; 0.5$ $\mathrm{g} / \mathrm{kg}$ of vitamin $\mathrm{B}_{2} ; 48 \mathrm{~g} / \mathrm{kg}$ of $\mathrm{Mg} ; 35 \mathrm{~g} / \mathrm{kg}$ of $\mathrm{Zn} ; 30 \mathrm{~g} / \mathrm{kg}$ of Mn; 23 $\mathrm{g} / \mathrm{kg}$ of Fe; $10 \mathrm{~g} / \mathrm{kg}$ of Cu; $0.6 \mathrm{~g} / \mathrm{kg}$ of I; $0.4 \mathrm{~g} / \mathrm{kg}$ of Co; $0.1 \mathrm{~g} / \mathrm{kg}$ of Se. ${ }^{2}$ Calculated following NRC (2001).

${ }^{3}$ Calculated as $(100-\mathrm{CP}-\mathrm{NDF}$ - ether extract - ash).

MR (6HF). Animals received MR for 5 consecutive weeks and then half the amount (either 3 or $2 \mathrm{~L} / \mathrm{d}$ depending on treatment) of MR for 1 additional week at $0800 \mathrm{~h}$ until weaning at d 42 of study. The study was completed 2 wk after weaning.

\section{Measurements and Sample Collection}

Individual MR and starter feed intakes were recorded daily and calves were weighed weekly. A glucose tolerance test (GTT) was performed on 24 calves (6 calves per treatment) on d 30 of study, as described elsewhere (Bach et al., 2013a). The sample size was decided by performing a power analysis using variability figures for the outcome variables from the literature. All blood samples were immediately placed on ice for at least 20 min and centrifuged at $3,500 \times g$ at $4^{\circ} \mathrm{C}$ for $15 \mathrm{~min}$; plasma or serum was decanted and stored at $-20^{\circ} \mathrm{C}$ until subsequent analysis. Concentrations of serum glucose were measured by spectrophotometry and plasma insulin concentration was determined by ELISA (Millipore porcine insulin, St. Charles, MO, with intra- and interassay coefficients of variation of 5.7 and $10.5 \%$, respectively).

One week after weaning (d 49 to 55 of study), plastic bags were glued to 6 animals per treatment (randomly selected) to determine apparent DM, CP, and fat apparent digestibility of the diet as described by Terré et al. (2007). During 5 consecutive days, all feces were collected and weighed. Bags were changed 3 times a 
day and fecal samples stored at $4^{\circ} \mathrm{C}$ until analysis. At the end of each day, a subsample equivalent to $30 \%$ of total daily feces weight was obtained and dried at $60^{\circ} \mathrm{C}$ for $72 \mathrm{~h}$. Subsamples of the $5 \mathrm{~d}$ were composited by animal, ground using a 1-mm screen (Cyclotech 1093 mill, Tecator, Höganäs, Sweden), and analyzed for DM, OM, $\mathrm{CP}$, and NDF following the methods described below.

\section{Chemical Analyses}

Samples of MR were analyzed for DM $(24 \mathrm{~h}$ at $\left.103^{\circ} \mathrm{C}\right)$, ash $\left(4 \mathrm{~h}\right.$ at $\left.550^{\circ} \mathrm{C}\right)$, and $\mathrm{N}$ content according to the method of the AOAC International (2000; method 988.05) adapted for an automatic distiller Kjeldahl (Kjeltec Auto 1030 Analyzer, Tecator) with copper sulfate/selenium as a catalyst instead of copper sulfate/ titanium dioxide. Samples of starter feed were analyzed for $\mathrm{DM}\left(4 \mathrm{~h}\right.$ at $\left.103^{\circ} \mathrm{C}\right)$, ash $\left(550^{\circ} \mathrm{C}\right.$ calcination), and $\mathrm{CP}$ with Kjeldahl analyses; NDF was analyzed with sodium sulfite and heat-stable $\alpha$-amylase (Van Soest et al., 1991), ADF was analyzed following AOAC International(2000; method 973.18), and ether extract following AOAC International (1990; method 920.39) with petroleum ether used for distillation instead of diethyl ether (AOAC International, 2000).

\section{Calculations and Statistical Analyses}

Nutrient apparent digestibility was calculated by dividing the difference between the quantity of nutrient consumed and defecated by the quantity of nutrient consumed. Metabolizable energy of MR and starter feeds as well as requirements of $\mathrm{ME}$ and $\mathrm{CP}$ of calves were calculated according to NRC (2001). Intake and growth data were summarized by week and animal before conducting statistical analyses.

Blood samples collected at -10 and 0 min relative to glucose infusion during the GTT were used to determine baseline concentrations of glucose and insulin. The area under the curve (concentration/min) for these 2 metabolites was calculated as the increase with respect to the baseline using the trapezoidal method. Then, clearance rates of insulin and glucose were computed as described elsewhere (Bach et al., 2013a). Insulin sensitivity was estimated using a simplification of the minimal model (Bergman, 1989) following Christoffersen et al. (2009).

Data pertaining to the GTT and apparent nutrient digestibility were analyzed using an ANOVA, accounting for the effects of MR allowance (4 or $6 \mathrm{~L} / \mathrm{d})$, fat content of the starter feed (4.1 or $11.2 \%$ ), and their interaction. Performance data were analyzed with a mixed-effects model for repeated measures. The statistical model included initial BW and age as covariates and accounted for the fixed effects of MR allowance, fat content of the starter feed, week of measurement, and their interactions, plus the random effect of calf.

\section{RESULTS AND DISCUSSION}

\section{Intake, Growth, and Digestibility}

Intake and performance data are depicted in Table 2. The BW data for wk 8 of study for most calves were lost because of an electronic problem with the scale. Thus, all data related to BW (BW, ADG, and gain-tofeed ratio) end at wk 7 of the study. Also, due to the study design, consumption of MR was greater for calves offered $6 \mathrm{~L} / \mathrm{d}$ than for those offered $4 \mathrm{~L} / \mathrm{d}$. Overall, fat content of the starter feed had no effect on MR or solid feed intake. Interestingly, starter feed intake overall was not affected by MR allowance. The lack of differences in starter feed intake between the $2 \mathrm{MR}$ allowances was mainly due to the low starter feed intake of $4 \mathrm{HF}$ calves. Calves in the $4 \mathrm{LF}$ treatment tended $(P=0.1)$ to have the greatest and $4 \mathrm{HF}$ the lowest starter feed intake. It is likely that the greater fat content of the starter feed may have induced satiety signals preventing $4 \mathrm{HF}$ calves from reaching similar starter feed intake levels as $4 \mathrm{LF}$ calves. Moreover, starter feed intake was greater $(P<$ $0.05)$ in LF compared with HF calves 2 wk after calves had been weaned (Figure 1).

Despite the lower amount of DM consumed by HF calves after weaning, ME intakes of HF and LF calves at wk 8 of the study (2 wk after weaning) were similar because of the greater fat content (and energy density) of the starter feed. In fact, fat intake was greater $(P<0.05)$ in HF compared with LF treatments from wk 2 of the study and thereafter. Again, satiety signals controlled by the energy balance of the animal may have been activated in calves consuming the HF starter feed, resulting in a milder increase in starter feed consumption (Montgomery and Baumgardt, 1965) after calves were weaned. Energy balance, calculated according to NRC (2001), was unaffected by the MR allowance or fat content of the starter feed (data not shown). However, LF calves had a lesser $(P<0.05)$ energy balance $(0.26 \pm 0.058 \mathrm{Mcal}$ of $\mathrm{ME} / \mathrm{d})$ during the week following weaning than HF calves (0.51 \pm 0.058 Mcal of ME/d), suggesting that perhaps energy balance limited DM intake in HF calves after weaning. Litherland et al. (2014) recently reported a lower starter feed intake when calves were supplemented with fat via MR but consumed similar ME intakes, and suggested that satiety mechanisms may have been responsible for the decrease in solid feed intake when supplementing fat in the MR. Metabolizable energy and fat consumption were greater for calves consuming 6 compared with $4 \mathrm{~L} / \mathrm{d}$ of MR from wk 1 to 5 of study 


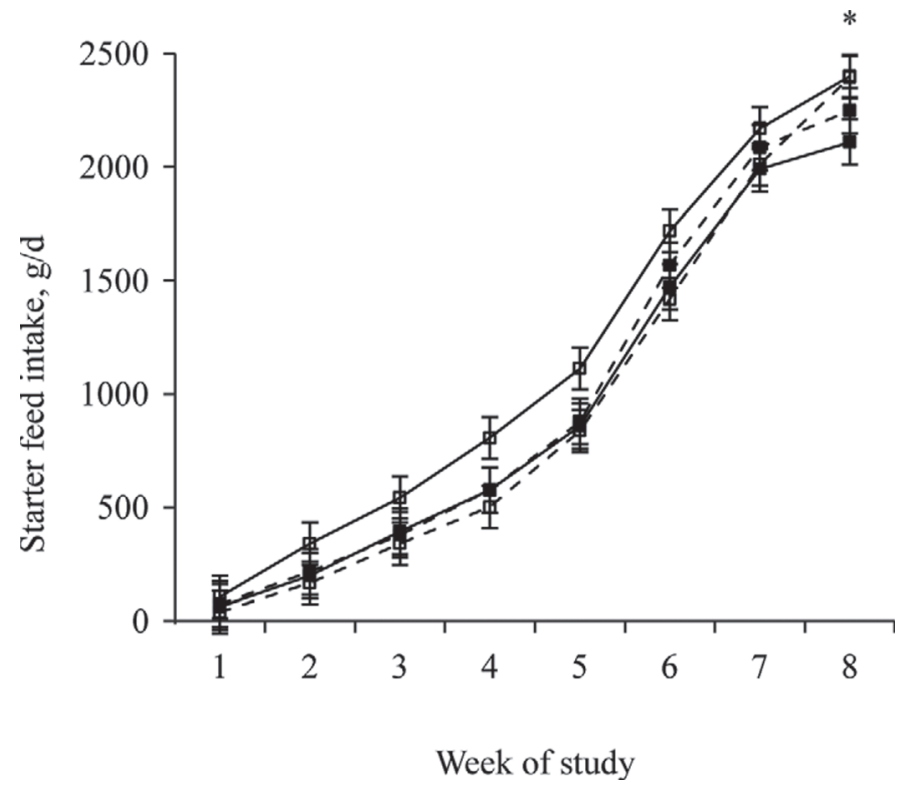

Figure 1. Starter feed intake of calves consuming $4 \mathrm{~L} / \mathrm{d}$ of $\mathrm{MR}$ (solid line) and a low fat $(-\square-; 4 \mathrm{LF})$ or a high fat $(-\square-; 4 \mathrm{HF})$ starter feed, and calves consuming $6 \mathrm{~L} / \mathrm{d}$ of $\mathrm{MR}$ (dashed line) and a low fat (-- $\square--; 6 \mathrm{LF})$ or a high fat (-- $\square--; 6 \mathrm{HF})$ starter feed. *Denotes differences $(P<0.05)$ between high- and low-fat starter feeds.

(when the full amount of MR was offered; Figure 2). After that, all calves consumed similar daily ME except during the first week after weaning (wk 7 of study), when $\mathrm{HF}$ calves had a greater $(P<0.05)$ ME intake than LF calves (due to the greater fat content of the HF starter feed; Figure 2). As expected, starter feed intake increased notably for all calves after weaning. However, solid feed consumption of HF calves stalled during the second week after weaning (wk 8 of study) and, as a consequence, the differences in ME intake observed in wk 7 of the study (greater in HF than in LF calves) disappeared. It could be speculated that feed intake of weaned calves was controlled by energy balance, which curtailed consumption of the starter feed with a high fat content.

As expected, protein intake was greater $(P<0.01)$ for calves consuming 6 compared with $4 \mathrm{~L} / \mathrm{d}$ of $\mathrm{MR}$ from wk 1 to 5 of the study when the full amount of MR was offered. However, protein intake was lower $(P$ $<0.05)$ in HF than in LF calves at wk 8, due to the lower starter feed intake observed for HF calves.

Apparent DM digestibility was unaffected by dietary treatments (Table 3). Interestingly, compared with LF calves, HF calves had greater $(P<0.05) \mathrm{CP}(74.3$ vs $77.9 \pm 1.72 \%$, respectively) and greater $(P<0.001)$ fat apparent digestibilities ( 72.0 vs $83.3 \pm 2.45 \%$; respectively). The lesser DM intake observed in HF calves during the week that digestibility was assessed may have slowed the passage rate of digesta, which might

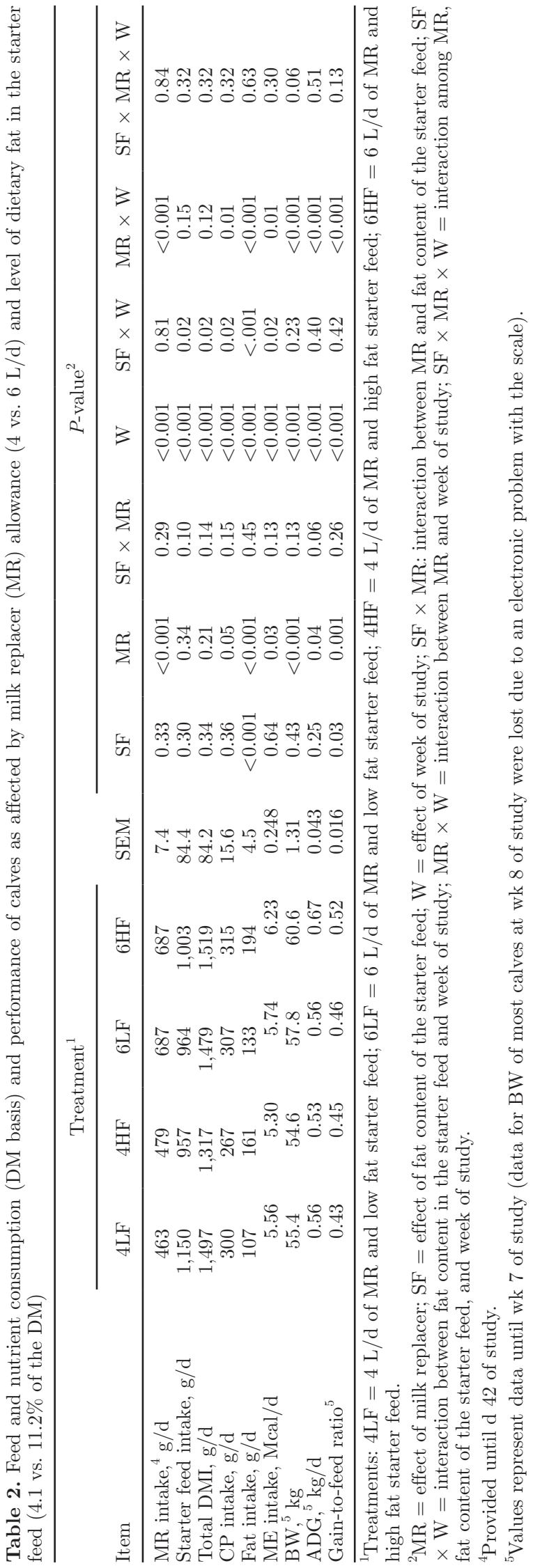




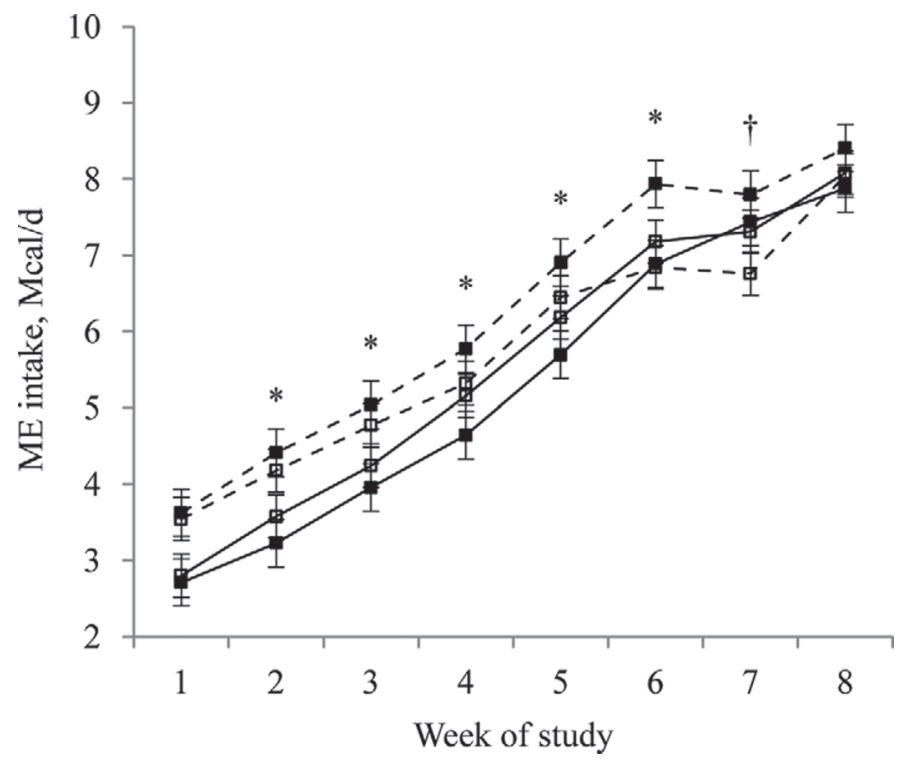

Figure 2. Metabolizable energy intake of calves consuming $4 \mathrm{~L} / \mathrm{d}$ of MR (solid line) and a low fat ( $-\square-$; 4LF) or a high fat (- $4 \mathrm{HF}$ ) starter feed, and calves consuming $6 \mathrm{~L} / \mathrm{d}$ of $\mathrm{MR}$ (dashed line) and a low fat (-- $\square--; 6 \mathrm{LF})$ or a high fat (-- --; 6HF) starter feed. *Denotes differences $(P<0.05)$ between 4 and $6 \mathrm{~L} / \mathrm{d}$ of $\mathrm{MR}$; †denotes differences $(P<0.05)$ between high- and low-fat starter feeds.

explain the increased protein and fat apparent digestibilities of HF compared with LF calves.

Despite the lack of differences in DM and ME intakes until weaning, calves in the $6 \mathrm{HF}$ treatment were heavier than calves in $4 \mathrm{LF}$ and $4 \mathrm{HF}$ treatments between wk 2 and the end of the study, and were heavier than $6 \mathrm{LF}$ calves from wk 5 to the end of the study (Figure 3). Furthermore, 6LF calves presented greater BW than $4 \mathrm{HF}$ calves between wk 3 of study and the week before weaning, and greater BW than $4 \mathrm{LF}$ calves between wk 4 of study and the week before weaning (Figure 3). Average daily gain was greater in calves on $6 \mathrm{~L} / \mathrm{d}$ of MR than in those on $4 \mathrm{~L} / \mathrm{d}$ of MR from wk 1 to 5 of study (immediately before starting to decrease the daily MR offer), but it was lower in wk 6 and 7 of study (around weaning). However, overall, 6HF calves tended
$(P=0.06)$ to grow more than calves in the other 3 treatments (Table 2). Gain-to-feed ratio during the first 3 wk of the study was greater $(P<0.001)$ for animals on $6 \mathrm{~L} / \mathrm{d}$ of MR compared with calves on $4 \mathrm{~L} / \mathrm{d}$ of MR (Table 2), as reported in other studies (Raeth-Knight et al., 2009; Terré et al., 2009; Stamey et al., 2012). This difference could be attributed to the greater MR intake in the calves on $6 \mathrm{~L} / \mathrm{d}$ of $\mathrm{MR}$ than in those on $4 \mathrm{~L} / \mathrm{d}$ of MR, which resulted in increased $\mathrm{CP}$ and $\mathrm{ME}$ intakes (Table 2) during the preweaning period (up to wk 6 of study). Moreover, gain-to-feed ratio was greater $(P<0.05)$ for calves consuming the HF starter feed compared with those consuming the LF starter feed (Table 2). This was probably due to the greater CP and fat apparent digestibilities found for calves in the HF treatment. Similar results have been reported when supplementing fat in the MR (Tikofsky et al., 2001; Litherland et al., 2014) of preweaned calves.

In general, when feeding calves on intensive feeding programs ( $6 \mathrm{~L} / \mathrm{d}$ of $\mathrm{MR})$, the 2 main problems observed are insufficient starter feed intake in the weeks before weaning and a consequent stall or slump in ADG during the weaning process (Cowles et al., 2006; Terré et al., 2009; Stamey et al., 2012). Some studies have reported a decrease in DM intake and growth when the fat content of the starter feed was above $4 \%$ of DM (Miller et al., 1959; Kuehn et al., 1994). However, in the present study, differences in starter feed intake around weaning were not significant, but a decrease in ADG the weeks before and after weaning (wk 6 and 7 of the study) was observed for calves fed $6 \mathrm{~L} / \mathrm{d}$ of MR compared with those fed $4 \mathrm{~L} / \mathrm{d}$. The advantage in BW reported in calves offered $6 \mathrm{~L} / \mathrm{d}$ of $\mathrm{MR}$ compared with those on $4 \mathrm{~L} / \mathrm{d}$ of $\mathrm{MR}$ during the weeks before weaning disappeared for $6 \mathrm{LF}$ calves when MR was reduced to one allotment per day but, interestingly, not for $6 \mathrm{HF}$ calves that continued to be at least $5 \mathrm{~kg}$ heavier than the calves in the other treatments at wk 7 of study. Others have reported an increase in BW before weaning when calves were fed large MR allowances (8 vs. $6 \mathrm{~L} / \mathrm{d}$; Bach et al., 2013b) or a fat supplement in MR

Table 3. Apparent digestibility (\%) as affected by milk replacer (MR) allowance (4 vs. $6 \mathrm{~L} / \mathrm{d})$ and level of dietary fat in the starter feed ( 4.1 vs. $11.2 \%$ of DM) of calves during the second week after weaning

\begin{tabular}{|c|c|c|c|c|c|c|c|c|}
\hline \multirow[b]{2}{*}{ Item } & \multicolumn{4}{|c|}{ Treament $^{1}$} & \multirow[b]{2}{*}{ SEM } & \multicolumn{3}{|c|}{$P$-value ${ }^{2}$} \\
\hline & $4 \mathrm{LF}$ & $4 \mathrm{HF}$ & $6 \mathrm{LF}$ & $6 \mathrm{HF}$ & & $\mathrm{SF}$ & MR & $\mathrm{SF} \times \mathrm{MR}$ \\
\hline DM & 80.8 & 83.1 & 80.2 & 81.4 & 1.55 & 0.20 & 0.36 & 0.74 \\
\hline $\mathrm{CP}$ & 74.5 & 79.6 & 74.1 & 76.2 & 1.72 & 0.04 & 0.15 & 0.47 \\
\hline Fat & 72.8 & 84.6 & 71.0 & 81.9 & 2.45 & $<0.001$ & 0.40 & 0.85 \\
\hline
\end{tabular}

${ }^{1}$ Treatments: $4 \mathrm{LF}=4 \mathrm{~L} / \mathrm{d}$ of $\mathrm{MR}$ and low fat starter feed; $6 \mathrm{LF}=6 \mathrm{~L} / \mathrm{d}$ of $\mathrm{MR}$ and low fat starter feed; $4 \mathrm{HF}$ $=4 \mathrm{~L} / \mathrm{d}$ of $\mathrm{MR}$ and high fat starter feed; $6 \mathrm{HF}=6 \mathrm{~L} / \mathrm{d}$ of $\mathrm{MR}$ and high fat starter feed.

${ }^{2} \mathrm{MR}=$ effect of milk replacer; $\mathrm{SF}=$ effect of fat content of the starter feed; $\mathrm{SF} \times \mathrm{MR}=$ interaction between $\mathrm{MR}$ and fat content of the starter feed. 
6516

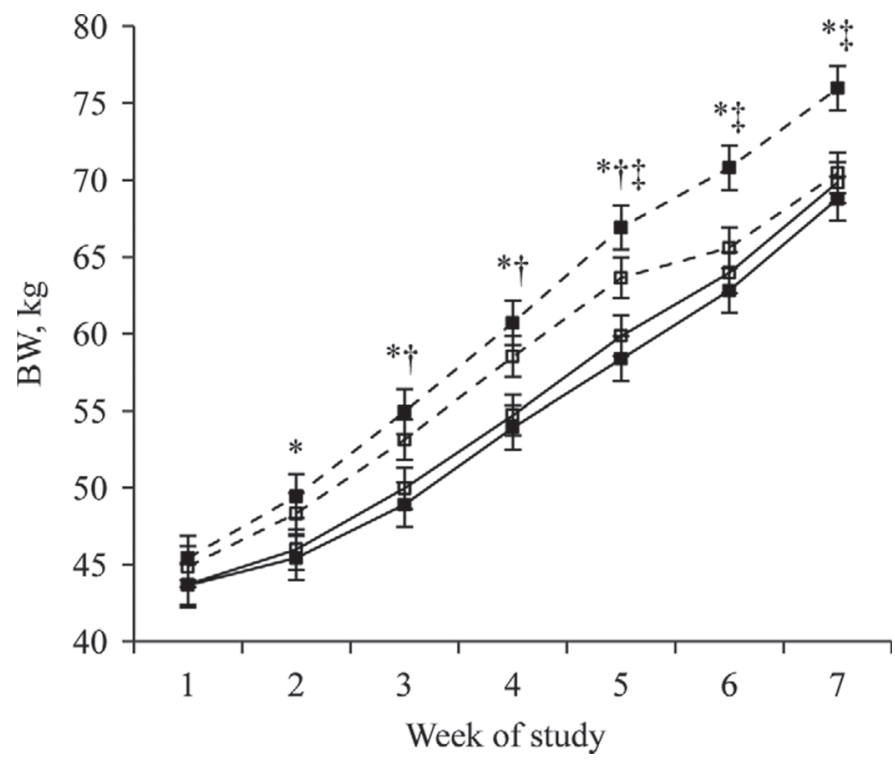

Figure 3. Body weight of calves consuming $4 \mathrm{~L} / \mathrm{d}$ of MR (solid line) and a low fat $(-\square-; 4 \mathrm{LF})$ or a high fat $(-\square-; 4 \mathrm{HF})$ starter feed, and calves consuming $6 \mathrm{~L} / \mathrm{d}$ of MR (dashed line) and a low fat ($\square--; 6 \mathrm{LF})$ or a high fat (--口--; $6 \mathrm{HF})$ starter feed. *Denotes differences $(P<0.05)$ between $6 \mathrm{HF}$ and $4 \mathrm{LH}$ and $4 \mathrm{HF}$; †denotes differences $(P<$ $0.05)$ between $4 \mathrm{HF}$ and $6 \mathrm{LF}$; $\ddagger$ denotes differences $(P<0.05)$ between $6 \mathrm{HF}$ and $6 \mathrm{LF}$. Data pertaining to BW of calves at wk 8 were lost due to an electronic problem with the scale.

(Litherland et al., 2014). However, Litherland et al. (2014) speculated that, due to a potential decrease in solid feed intake when supplementing MR with fat, the dietary CP:ME ratio may decrease and limit growth. However, in the current study, dietary CP:ME ratio ranged between 50.4 and $54.0 \mathrm{~g}$ of $\mathrm{CP} / \mathrm{Mcal}$ of $\mathrm{ME}$. Thus, as suggested by Donnelly (1983), who reported that dietary CP:ME ratios around $54 \mathrm{~g}$ of $\mathrm{CP} / \mathrm{Mcal}$ of $\mathrm{ME}$ should not compromise growth of calves, and Hill et al. (2009), who reported maximal growth with dietary CP:ME ratios between 51.5 and $55.0 \mathrm{~g}$ of $\mathrm{CP} /$ Mcal of ME, it is unlikely that CP intake in the current study limited growth. Nevertheless, some studies have reported that increasing fat in diets of calves results in increased body fat deposition (Tikofsky et al., 2001; Bascom et al., 2007) when calves are fed a high-fat diet with a dietary CP:ME ratio between 45.8 and $50.1 \mathrm{~g}$ of $\mathrm{CP} / \mathrm{Mcal}$ of ME. In the current study, calves in the $6 \mathrm{HF}$ treatment consumed $50.6 \mathrm{~g}$ of $\mathrm{CP} / \mathrm{Mcal}$ of $\mathrm{ME}$, and thus they might have increased body fat accretion. However, the efficiency of fat deposition is lower than that of muscle deposition and no differences were found in gain-to-feed ratio between $6 \mathrm{LF}$ and $6 \mathrm{HF}$ treatments in the present study, which would indicate that fattening in 6HF may have been minimal. In fact, both Tikofsky et al. (2001) and Bascom et al. (2007) reported differences in gain-to-feed ratio between high- and low-fat diets, whereas, in the current study, calves consuming HF treatments did not have lower feed efficiencies than calves on LF treatments. Moreover, calves in the studies by Tikofsky et al. (2001) and Bascom et al. (2007) were fed exclusively MR, whereas in the present study fat was supplemented in the starter feed, which may lead to different metabolic responses. Then, it is likely that the extra energy consumed by $6 \mathrm{HF}$ calves resulted in more growth without incurring increased fat deposition. Therefore, we can conclude that a starter feed high in fat may help to attenuate the stall or slump in growth around weaning in calves raised on an intensive feeding program $(\sim 6 \mathrm{~L} / \mathrm{d}$ of $\mathrm{MR})$.

\section{GTT}

We hypothesized that an increased fat or energy supply to young calves might alter glucose metabolism. However, the parameters evaluated with the GTT were not affected by treatments (Table 4) conducted on d 30 of the study, except for the basal serum glucose concentration, which was greater $(P<0.05)$ for calves fed $6 \mathrm{~L} / \mathrm{d}$ of MR compared with those receiving $4 \mathrm{~L} / \mathrm{d}$ of MR. Mean serum glucose concentration during the GTT tended $(P=0.10)$ to be greater for calves consuming $6 \mathrm{~L} / \mathrm{d}$ of MR than for those consuming $4 \mathrm{~L} / \mathrm{d}$ of MR. Metabolic disorders such as impaired insulin function may be present when large amounts of MR are fed to calves in a single allotment (Bach et al., 2013a). However, in the current study, no differences in plasma insulin levels were found for calves fed $6 \mathrm{~L} / \mathrm{d}$ of MR compared with those fed $4 \mathrm{~L} / \mathrm{d}$ of MR, and insulin sensitivity was similar among treatments. This is in contrast to the insulin resistance previously reported by Bach et al. (2013a) when offering $8 \mathrm{~L} / \mathrm{d}$ of MR (2 daily allotments of $4 \mathrm{~L}$ ) and to the increase in insulinto-glucose ratio reported by Terré et al. (2009), when calves received 2 allotments of $4 \mathrm{~L}$ per day. Probably, offering $6 \mathrm{~L} / \mathrm{d}$ of MR (3 L per allotment) to suckling calves is not sufficient to elicit the negative changes in insulin function observed when offering larger volumes.

Interestingly, glucose clearance rate tended $(P=$ $0.09)$ to be greater for calves consuming LF than for calves consuming HF. This is in contrast to results from previous studies (Palmquist et al., 1992) wherein calves fed low-fat diets tended to decrease glucose utilization rates with age and had lower glucose and insulin areas under the curve. Because of differences in nutrient composition of the starter feed, calves fed LF diets consumed proportionally more NFC than calves fed HF after weaning. Then, the transition from a diet rich in fat from MR to a diet rich in NFC from the starter feed was more abrupt in calves fed LF than in those fed HF. 
Table 4. Glucose and insulin responses to an intravenous glucose tolerance test (performed on d 30 of study) of calves as affected by milk replacer $(\mathrm{MR})$ allowance $(4$ vs. $6 \mathrm{~L} / \mathrm{d})$ and level of dietary fat in the starter feed $(4.1$ vs. $11.2 \%$ of the DM)

\begin{tabular}{|c|c|c|c|c|c|c|c|c|}
\hline \multirow[b]{2}{*}{ Item $^{1}$} & \multicolumn{4}{|c|}{ Treament $^{2}$} & \multirow[b]{2}{*}{ SEM } & \multicolumn{3}{|c|}{$P$-value ${ }^{3}$} \\
\hline & $4 \mathrm{LF}$ & $4 \mathrm{HF}$ & $6 \mathrm{LF}$ & $6 \mathrm{HF}$ & & $\mathrm{SF}$ & MR & $\mathrm{SF} \times \mathrm{MR}$ \\
\hline Glucose, $\mathrm{mmol} / \mathrm{L}$ & 5.9 & 5.9 & 6.6 & 6.3 & 0.32 & 0.62 & 0.10 & 0.68 \\
\hline Insulin, $\mu \mathrm{U} / \mathrm{mL}$ & 42.3 & 39.5 & 45.6 & 48.9 & 8.03 & 0.97 & 0.44 & 0.71 \\
\hline Glucose AUC, mmol/L & 73.2 & 77.4 & 60.7 & 80.5 & 12.06 & 0.33 & 0.70 & 0.53 \\
\hline Insulin AUC, $\mu \mathrm{U} / \mathrm{mL}$ & 1,313 & 1,323 & 1,241 & 1,403 & 335.2 & 0.80 & 0.99 & 0.82 \\
\hline Insulin peak, $\mu \mathrm{U} / \mathrm{mL}$ & 67.0 & 70.4 & 59.2 & 66.1 & 5.00 & 0.32 & 0.24 & 0.73 \\
\hline Insulin nadir, $\mu \mathrm{U} / \mathrm{mL}$ & 7.8 & 7.7 & 7.4 & 11.0 & 2.44 & 0.48 & 0.56 & 0.46 \\
\hline Time to glucose peak, min & 4.0 & 4.0 & 4.0 & 4.0 & 0.00 & - & - & - \\
\hline Time glucose nadir, min & 41.7 & 46.7 & 35.8 & 43.3 & 5.61 & 0.28 & 0.42 & 0.83 \\
\hline Time to insulin peak, min & 15.5 & 10.0 & 11.3 & 12.2 & 2.60 & 0.38 & 0.70 & 0.24 \\
\hline Time to insulin nadir, min & 50.8 & 57.5 & 46.7 & 50.8 & 4.04 & 0.20 & 0.20 & 0.76 \\
\hline $\mathrm{GCR}, \mathrm{mmol} / \mathrm{L} \cdot \min$ & 7.7 & 5.7 & 8.1 & 5.7 & 1.20 & 0.09 & 0.90 & 0.88 \\
\hline
\end{tabular}

${ }^{1} \mathrm{AUC}=$ area under the curve; $\mathrm{GCR}=$ glucose clearance rate; ICR $=$ insulin clearance rate.

${ }^{2}$ Treatments: $4 \mathrm{LF}=4 \mathrm{~L} / \mathrm{d}$ of $\mathrm{MR}$ and low fat starter feed; $6 \mathrm{LF}=6 \mathrm{~L} / \mathrm{d}$ of $\mathrm{MR}$ and low fat starter feed; $4 \mathrm{HF}=4 \mathrm{~L} / \mathrm{d}$ of $\mathrm{MR}$ and high fat starter feed; $6 \mathrm{HF}=6 \mathrm{~L} / \mathrm{d}$ of $\mathrm{MR}$ and high fat starter feed.

${ }^{3} \mathrm{MR}=$ effect of milk replacer; $\mathrm{SF}=$ effect of fat content of the starter feed; SF $\times \mathrm{MR}=$ interaction between MR and fat content of the starter feed.

${ }^{4}$ Calculated following Christoffersen et al. (2009).

This may have influenced glucose metabolism of calves fed the LF starter feed.

\section{CONCLUSIONS}

Growth performance of calves consuming $6 \mathrm{~L} / \mathrm{d}$ of $\mathrm{MR}$ was greater than that of calves consuming $4 \mathrm{~L} / \mathrm{d}$ before weaning. Although feeding a high-fat starter feed depressed intake after weaning, increasing the fat content of the starter feed to $11.2 \%$ when offering $6 \mathrm{~L} / \mathrm{d}$ of milk replacer increased overall $\mathrm{BW}$ and tended to increase growth. Thus, feeding a starter feed high in fat may help to attenuate the slump in growth at weaning in calves raised on intensive feeding programs.

\section{REFERENCES}

AOAC International. 2000. Official Methods of Analysis. Vol. I. 17th ed. AOAC International, Arlington, VA.

Bach, A. 2011. Associations between several aspects of heifer development and dairy cow survivability to second lactation. J. Dairy Sci. 94:1052-1057.

Bach, A. 2012. Ruminant Nutrition Symposium: Optimizing Performance of the Offspring: Nourishing and managing the dam and postnatal calf for optimal lactation, reproduction, and immunity. J. Anim. Sci. 90:1835-1845.

Bach, A., L. Domingo, C. Montoro, and M. Terré. 2013a. Short communication: Insulin responsiveness is affected by the level of milk replacer offered to young calves. J. Dairy Sci. 96:4634-4637.
Bach, A., M. Terré, and A. Pinto. 2013b. Performance and health responses of dairy calves offered different milk replacer allowances. J. Dairy Sci. 96:7790-7797.

Bascom, S. A., R. E. James, M. L. McGilliard, and M. VanAmburgh. 2007. Influence of dietary fat and protein on body composition of Jersey bull calves. J. Dairy Sci. 90:5600-5609.

Bergman, R. N. 1989. Lilly lecture 1989. Toward physiological understanding of glucose tolerance. Minimal-model approach. Diabetes 38:1512-1527.

Christoffersen, B., U. Ribel, K. Raun, V. Golozoubova, and G. Pacini. 2009. Evaluation of different methods for assessment of insulin sensitivity in Göttingen minipigs: Introduction of a new, simpler method. Am. J. Physiol. Regul. Integr. Comp. Physiol. 297:R1195-R1201.

Cowles, K. E., R. A. White, N. L. Whitehouse, and P. S. Erickson. 2006. Growth characteristics of calves fed an intensified milk replacer regimen with additional lactoferrin. J. Dairy Sci. 89:48354845.

Davis Rincker, L. E., M. J. VandeHaar, C. A. Wolf, J. S. Liesman, L. T. Chapin, and M. S. Weber Nielsen. 2011. Effect of intensified feeding of heifer calves on growth, pubertal age, calving age, milk yield, and economics. J. Dairy Sci. 94:3554-3567.

Donnelly, P. E. 1983. Effects of dietary carbohydrate:fat ratio on growth and body composition of milk-fed calves. N. Z. J. Agric Res. 26:71-77.

Hill, T. M., H. G. Bateman II, J. M. Aldrich, and R. L. Schlotterbeck. 2007. Effects of feeding rate of milk replacers and bedding material for calves in a cold, naturally ventilated nursery. Prof. Anim. Sci. 23:656-664.

Hill, T. M., H. G. Bateman II, J. M. Aldrich, and R. L. Schlotterbeck. 2009. Effects of fat concentration of a high-protein milk replacer on calf performance. J. Dairy Sci. 92:5147-5153.

Hill, T. M., H. G. Bateman II, J. M. Aldrich, and R. L. Schlotterbeck. 2010. Effect of milk replacer program on digestion of nutrients in dairy calves. J. Dairy Sci. 93:1105-1115. 
Jasper, J., and D. M. Weary. 2002. Effects of ad libitum milk intake on dairy calves. J. Dairy Sci. 85:3054-3058.

Johnson, D. Jr., K. L. Dolge, J. E. Rousseau Jr., R. Teichman, and H. D. Eaton. 1956. Effect of addition of inedible tallow to a calf starter fed to Holstein calves. J. Dairy Sci. 39:1268-1279.

Kubota, N., Y. Terauchi, H. Miki, H. Tamemoto, T. Yamauchi, K. Komeda, S. Satoh, R. Nakano, C. Ishii, T. Sugiyama, K. Eto, Y. Tsubamoto, A. Okuno, K. Murakami, H. Sekihara, G. Hasegawa, M. Naito, Y. Toyoshima, S. Tanaka, K. Shiota, T. Kitamura, T. Fujita, O. Ezaki, S. Aizawa, and T. Kadowaki. 1999. PPAR gamma mediates high-fat diet-induced adipocyte hypertrophy and insulin resistance. Mol. Cell 4:597-609.

Kuehn, C. S., D. E. Otterby, and J. G. Linn. 1994. The effect of dietary energy concentration on calf performance. J. Dairy Sci. $77: 2621-2629$.

Litherland, N. B., D. N. L. Da Silva, R. J. LaBerge, J. Schefers, and A. Kertz. 2014. Supplemental fat for dairy calves during mild cold stress. J. Dairy Sci. 97:2980-2989.

Miller, W. J., J. L. Carmon, and H. L. Dalton. 1959. Influence of high levels of plant and animal fats in calf starters on growth, feed consumption, and palatability. J. Dairy Sci. 42:153-158.

Montgomery, M. J., and B. R. Baumgardt. 1965. Regulation of food intake in ruminants. 1. Pelleted rations varying in energy concentration. J. Dairy Sci. 48:569-574.

Montoro, C., and A. Bach. 2012. Voluntary selection of starter feed ingredients offered separately to nursing calves. Livest. Sci. 149:6269.

NRC. 2001. Nutrient Requirements of Dairy Cattle. 7th rev. ed. Natl. Acad. Press., Washington, DC.
Palmquist, D. L., J. Doppenberg, K. L. Roehrig, and D. J. Kinsey 1992. Glucose and insulin metabolism in ruminating and veal calves fed high and low fat diets. Domest. Anim. Endocrinol. 9:233-241.

Raeth-Knight, M., H. Chester-Jones, S. Hayes, J. Linn, R. Larson, D. Ziegler, B. Ziegler, and N. Broadwater. 2009. Impact of conventional or intensive milk replacer programs on Holstein heifer performance through six months of age and during first lactation. J. Dairy Sci. 92:799-809.

Stamey, J. A., N. A. Janovick, A. F. Kertz, and J. K. Drackley. 2012 Influence of starter protein content on growth of dairy calves in an enhanced early nutrition program. J. Dairy Sci. 95:3327-3336.

Suárez-Mena, F. X.. T. M. Hill, A. J. Heinrichs, H. G. Bateman II, J. M. Aldrich, and R. L. Schlotterbeck. 2011. Effects of including corn distillers dried grain with solubles in dairy calf feeds. J. Dairy Sci. 94:3037-3044

Terré, M., M. Devant, and A. Bach. 2007. Effect of level of milk replacer fed to Holstein calves on performance during the preweaning period and starter digestibility at weaning. Livest. Sci. 110:82-88.

Terré, M., C. Tejero, and A. Bach. 2009. Long-term effects on heifer performance of an enhanced-growth feeding programme applied during the preweaning period. J. Dairy Res. 76:331-339.

Tikofsky, J. N., M. E. Van Amburgh, and D. A. Ross. 2001. Effect of varying carbohydrate and fat content of milk replacer on body composition of Holstein bull calves. J. Anim. Sci. 79:2260-2267.

Van Soest, P. J., J. B. Robertson, and B. A. Lewis. 1991. Methods for dietary fiber, neutral detergent fiber, and nonstarch polysaccharides in relation to animal nutrition. J. Dairy Sci. 74:3583-3597. 